\title{
Miranda
}

Revue pluridisciplinaire du monde anglophone /

Multidisciplinary peer-reviewed journal on the English-

speaking world

15 | 2017

Lolita at 60 / Staging American Bodies

\section{Agnès Derail and Cécile Roudeau (eds.), James Fenimore Cooper ou la frontière mélancolique: The Last of the Mohicans et The Leatherstocking Tales}

\section{Wendy Harding}

\section{OpenEdition}

\section{Journals}

Electronic version

URL: http://journals.openedition.org/miranda/10879

DOI: $10.4000 /$ miranda. 10879

ISSN: 2108-6559

\section{Publisher}

Université Toulouse - Jean Jaurès

\section{Electronic reference}

Wendy Harding, "Agnès Derail and Cécile Roudeau (eds.), James Fenimore Cooper ou la frontière mélancolique : The Last of the Mohicans et The Leatherstocking Tales ", Miranda [Online], 15 | 2017, Online since 20 September 2017, connection on 16 February 2021. URL: http://

journals.openedition.org/miranda/10879 ; DOI: https://doi.org/10.4000/miranda.10879

This text was automatically generated on 16 February 2021.

\section{cc)}

Miranda is licensed under a Creative Commons Attribution-NonCommercial-NoDerivatives 4.0

International License. 


\title{
Agnès Derail and Cécile Roudeau (eds.), James Fenimore Cooper ou la frontière mélancolique: The Last of the Mohicans et The Leatherstocking Tales
}

\author{
Wendy Harding
}

\section{REFERENCES}

Agnès Derail and Cécile Roudeau (eds.), James Fenimore Cooper ou la frontière mélancolique : The Last of the Mohicans et The Leatherstocking Tales, Paris : Editions Rue d'Ulm, 2016, 154p, ISBN-978-2-7288-3596-6

If there were any doubts concerning the importance of James Fenimore Cooper's contribution to American letters, this slim volume of essays edited by Agnès Derail and Cécile Roudeau puts them to rest. Though Cooper's Leatherstocking novels were immediately popular at the time of publication, later criticism raised questions about their literary value. In particular Mark Twain's pointed critique, "James Fenimore Cooper's Literary Offences" (1895), lampooned such features as the author's unwieldy sentences and unrealistic turns of plot. In spite of those unfashionable traits, since their publication the Leatherstocking novels have been read by generations of readers, and The Last of the Mohicans has been translated into many languages and media. This collection of essays explores some of the ways in which Cooper's Leatherstocking novels succeed in forging a distinctly American mythology in their coupling of history and romance. The Leatherstocking series maps the expansion of the new nation, presenting what the collection names the melancholy frontier, "la frontière mélancolique" referred to in its title. 
2 The introduction by Agnès Derail and Cécile Roudeau is an essay in its own right. The editors present the work of the other contributors only very briefly in the last paragraph of their preface. Their contribution introduces Cooper rather than the other critics, summarizing how his work forges an enduring myth for American culture. In particular, their essay emphasizes how The Last of the Mohicans mourns the effects of imperialist violence on the land and its indigenous peoples. Nevertheless, as the authors point out, the novel's melancholy cast is also a posture ; the narrative returns to the nation's past so as better to move America forward into the future. Cooper imagines a multi-racial ideal in coupling Uncas and Cora, but their unrealized union, only suggested at their funeral, leaves the way open for the Anglo-American pairing of Alice and Duncan Heywood. The narrator speaks from the time of that couple's future, drawing attention at key moments to a double time frame in which the past of the narrative contrasts with the post-Revolutionary present of the novel's writing.

Cooper's concerns with history, trauma, and American culture are addressed in different ways in the essays that follow. Although the collection brings together the work of a number of contributors, each with a distinctive approach, it is nicely focused on the idea of melancholy. The volume is slim, which keeps it at an affordable price for students. The contributions are of high quality, coming from some of the most respected French scholars of nineteenth century American literature as well as some of the most promising younger ones. Rather than entering into debate with the critical corpus, the authors have privileged engaging with the Leatherstocking novels themselves and their cultural and literary intertexts, including other works by Cooper.

Ronan Ludot-Vlasak's essay, "Les spectres shakespeariens de The Last of the Mohicans", takes as a point of departure Cooper's evident reverence for Shakespearean drama. Other critics have noted and quantified Cooper's numerous references to the English dramatist; Ludot-Vlasak's contribution to this scholarly tradition resides in his detailed analysis of the varied ways in which The Last of the Mohicans engages with the hypotext. First, like Shakespeare, Cooper highlights the theatricality of the action and underscores the ways in which identity is a game of masks. Scripted codes of behavior produce a spectacle that serves to hide the underlying barbarity of imperial warfare. Parallels with Shakespearean tragedy bring out the absurdity of war and the evil of participants.

5 Pauline Pilote looks at another important intertext in her essay, "This picturesque land of ours'. La mise en valeur du paysage national dans les romans écossais de Walter Scott et dans The Last of The Mohicans de James Fenimore Cooper". She shows how Cooper manages to create a national literature that both resonates with and departs from Scott's own project of mapping his native land. The American author does this by transforming the conventions of the Romantic novel for the national territory. In The Last of The Mohicans, the wilderness both recalls and contrasts with Scott's Scottish landscapes. This essay shows that the American setting is more grandiose, more terrifying, and less a simple background than an actor in the plot. Moreover, Cooper's wilderness is not devoid of history, for within a very short time the traces of past battles furnish it with gothic ruins.

6 Further exploring the landscape of the The Last of the Mohicans from the unusual perspective of the depiction of water, Emilia Le Seven points out the continuity between Cooper's maritime novels and this fictional rendering of events and scenes from 1757. The quotation included in the essay's title, "water leaves no trail", is a point 
of departure for an exploration of the ways in which, on the contrary, the aquatic element does indeed leave traces that are readable by the novel's expert trackers. In discerning the signs left in water-the marks of passage and of violence-Cooper's trio of foresters demonstrate their expertise in reading the book of nature. The narrative's treatment of water invites readers to look beyond appearance and to pay attention to the ways in which historical events make their mark on the apparently virgin surface of the American landscape.

7 Julian Nègre's contribution to this volume focuses on the novel that deals with Leatherstocking's final years. In The Prairie the main protagonist of the series follows the course of American empire by migrating westward, beyond the settlements. Nègre contrasts the way in which Cooper gives historical relief to the New York landscape of The Last of the Mohicans with the restraint he exercises in his depiction of the western prairie. This study of the novel shows Cooper's debt to Stephen Long's map of the region that the cartographer labeled "the Great Desert". Indeed, Cooper's plains are quasi-empty. Like Long's map, the novel represents the prairie as a smooth, nomadic space, inhospitable to settlement. Insofar as the novel takes on the work of mapping, it does so by using abstract geometric points of orientation, following the logic of the grid or of nautical cartography. Appropriately, the prairie is the site of Natty Bumppo's tomb, since its settlement is bound to bring on the end of the nomadic way of life. The Prairie fits into the model of the melancholy frontier because it resists the progressive vision of history and imbues the westward movement of Euro-American settlers with a sense of regret for their exploitative relation with the environment.

8 In "L'après-Cooper: logique de l'après-coup dans The Last of the Mohicans", Marc Amfreville considers the applicability of the Freudian notion of Nachträglichkeit, or the "après-coup" in French, usually translated as "afterwardsness" or "deferred action" in English. The essay begins with a reflection on the concept itself, one that Amfreville claims to have been anticipated by Cooper before Freud articulated it as a psychoanalytical phenomenon. Its pertinence to the novel derives from several features, including the way in which the deaths at the end repeat the trauma of the historical massacre at the center of the novel. Colonization leads to fratricide among and between Europeans and Native Americans. The text plays with time in staging the uncanny scene in which the father mourns his heir, witnessing the end of his line. In Amfreville's very subtle inquiry into the similarities between history and fiction, the melancholy (personal and national) that is the focus of this collection takes on its full significance.

9 Like Marc Amfreville, Mark Niemeyer takes up the question of the resonance between America's fictions and its history. His contribution looks at the recurring trope of the Vanishing Indian. The essay considers how The Last of the Mohicans takes its place in a continuum of artistic and literary representations of the demise of indigenous Americans. The romanticizing of Indians as a dying race only became possible once the threat they posed to settlement had been distanced. It is at that point that the national work of mourning could begin for a way of life that imperial expansion had worked to destroy. Still, as Niemeyer points out, Cooper's text leaves open the possibility of future resurgence, hence the choice of the word "allochronic" in his title, to refer to a time different from the present.

The final contributions to the volume by Pierre-Yves Pétillon take the form of interrelated notations rather than a developed essay. "Nathanaël avant et après; ou de 
prolepse en anamnèse", ranges across all five novels of the Leatherstocking saga to give a biography of the protagonist. Different sections of this contribution deal with the various aspects of the hero's characterization, from the multiple names by which he is known, to his ethical code, religion or attitude to race. There follows in a section entitled "Annexe: arrière-plan" a recapitulation of some of the novels' historical underpinnings as well as a discussion of Cooper's own relation to the history covered in the Leatherstocking series.

11 Students and scholars of American literature will find much to recommend in this volume. It contains an excellent bibliography that includes all of Cooper's writings, as well as selected texts by his contemporaries. Besides a listing of literary studies on Cooper, his sources, and more generally on literary genres, there is a quite extensive list of works on history, American Indians, representations of the American territory. One can only regret that the collection is really available only to French speakers, since just one of the essays is written in English.

\section{INDEX}

Keywords: Native Americans, cartography, frontier, history, imperialism, Indians, Leatherstocking, melancholy, trauma

Mots-clés: Amérindiens, Bas-de-Cuir, cartographie, frontière, histoire, impérialisme, mélancolie, traumatisme

\section{AUTHORS}

\section{WENDY HARDING}

Professeur des Universités

Université Toulouse Jean-Jaurès

harding@univ-tlse2.fr 